\title{
Olusegun Vincent* \\ CENTRAL BANKS' RESPONSE TO INFLATION, OUTPUT GAP, AND EXCHANGE RATE IN NIGERIA AND SOUTH AFRICA
}

This study examines inflation targeting in Nigeria and South Africa, using fully modified least square to estimate a modified Taylor rule for the period 1970 to 2016. The study unravels evidence of a significant response of inflation and squared inflation to policy interest rates in South Africa, but not in Nigeria. Overall, South Africa's central bank places much emphasis on inflation targeting in setting interest rates which Nigeria does not. Further, for South Africa, output gap is significant, while it is not significant for Nigeria. The study also reveals that exchange rate, openness to trade and international reserves play significant roles in central bank policy in both countries. In other words, there is need for central banks to adopt an eclectic approach, setting the monetary policy rule to adjust to any observed disequilibrium between output gap, inflation, exchange rate, foreign reserves and openness to trade. However, strict inflation targeting may not serve as an appropriate framework to address the crucial macroeconomic problems challenging these African economies.

Keywords: Central Bank, Exchange Rate, FM-OLS, Inflation, Inflation Targeting, Monetary Policy, Output Gap, Taylor Rule

JEL Classification: E00, E04, E43, F00, G12, G17.

For. 9. Tab. 3. Lit. 68 .

Peer-reviewed, approved and placed: 16.01.2020.

DOI: $10.32752 / 1993-6788-2020-1-223-42-54$

\section{Олусегун Вінсент \\ РЕАКЦІЯ ЦЕНТРАЛЬНИХ БАНКІВ НА ІНФЛЯЦІЮ, РОЗРИВ В ОБСЯЗІ ВИРОБНИЦТВА ТА ОБМІННИЙ КУРС В НІГЕРІЇ ТА ПІВДЕННІЙ АФРИЦІ}

У цьому дослідженні вивчається націлювання на інфляцію в Нігерії та Південній Африці, використовуючи повністю модифікований найменший квадрат для оцінки модифікованого правила Тейлора на період з 1970 по 2016 рік. Дослідження розкриває докази значної реакції інфляції та квадрату інфляції на політичні процентні ставки в Південній Африці, але не в Нігерії. Загалом центральний банк Південної Африки приділяє значну увагу націленню на інфляцію при встановленні процентних ставок, чого не робить Нігерія. Крім того, для Південної Африки розрив у виробництві є значним, тоді як для Нігерії він не є значним. Дослідження також виявляє, що обмінний курс, відкритість до торгівлі та міжнародні резерви відіграють важсливу роль у політиці центрального банку в обох крайнах. Іншими словами, існує необхідість у центральних банках застосувати еклектичний підхід, встановлюючи правило грошово-кредитної політики з урахуванням будь-якої спостерігається нерівноваги між розривом у випуску, інфляцією, обмінним курсом, іноземними резервами та відкритістю для торгівлі. Однак суворе націлювання на інфляцію може не слугувати відповідною основою для вирішення найважливіших макроекономічних проблем, що стоять перед цими африканськими економіками.

Ключові слова: Центральний банк, валютний курс, FM-OLS, інфляція, націлювання на інфляцію, грошово-кредитна політика, розрив в обсязі виробництва, правило Тейлора.

*Pan-Atlantic University, Lagos, Nigeria.

(c) Olusegun Vincent, 2020 


\section{Олусегун Винсент \\ РЕАКЦИЯ ЦЕНТРАЛЬНЫХ БАНКОВ НА ИНФЛЯЦИЮ, РАЗРЫВ ВЫПУСКА И ОБМЕННЫЙ КУРС В НИГЕРИИ И ЮЖНОЙ АФРИКЕ}

В этом исследовании изучается таргетирование инфляции в Нигерии и Южной Африке с использованием полностью модифицированного метода наименьших квадратов для оценки модифицированного правила Тейлора на период с 1970 по 2016 год. Исследование раскрывает свидетельства значительной реакции инфляции и квадрата инфляции на политические процентные ставки в Южной Африке. но не в Нигерии. В целом центральный банк Южной Африки уделяет большое внимание таргетированию инфляции при установлении процентных ставок, чего не делает Нигерия. Кроме того, для Южной Африки разрыв объема производтвва значительный, в то время как для Нигерии он незначителен. Исследование также показывает, ито обменный курс, открытость для торговли и международные резервы играют важную роль в политике центральных банков в обеих странах. Другими словами, центральным банкам необходимо принять эклектичный подход, установив правило денежно-кредитной политики, чтобы приспособиться к любому наблюдаемому неравновесию между разрывом выпуска, инфлящией, обменным курсом, иностранными резервами и открытостью для торговли. Однако строгое таргетирование инфляции может не служить подходящей основой для решения серьезных макроэкономических проблем, стоящих перед экономикой этих африканских стран.

Ключевые слова: Центральный банк, обменный курс, FM-OLS, инфляция, таргетирование инфляции, денежно-кредитная политика, разрыв выпуска, правило Тейлора.

1. Introduction. Inflation targeting (IT) is a framework whereby "an inflation objective is announced and a clear commitment to achieve this objective is spelled out. This helps shape the public's expectations, consequently helping planning and also providing an anchor for expectations of future inflation to influence price and wage setting decisions" (Naraidoo and Gupta, 2010). IT has become a normal operating procedure in central banks globally (Aizenman, Hutchison and Noy, 2008; Bordo and Levin, 2017; Bernanke, Laubach, Mishkin and Posen, 2018; Katusiime and Agbola, 2018). In Africa, a number of countries like South Africa have adopted IT and they did so mainly as a result of its apparent success in rendering low stable inflation in countries such as Canada, New Zealand, and the United Kingdom.

Between 1960 and 1998, South Africa's monetary policy strategy included monetary-aggregate targeting, exchange-rate targeting, discretionary monetary policy, and an eclectic approach. These periods involve instituting some pre-announced M3 and other intermediate targets (such as exchange rates). Formal IT was introduced in 2000 (Jonsson 2001; van der Merwe, 2004). In Nigeria, different monetary policy regimes have been adopted over the years with rather unsatisfactory success (Nwaogwugwu and Evans, 2016; Saibu, Alenoghena, Evans and Tewogbade, 2016; Evans, 2017; Evans and Saibu, 2017; Evans et al, 2018). These policies ranged from direct monetary controls, exchange rate targeting, to monetary targeting (Bassey and Essien, 2014; Adeniji, Obansa and Okoroafor, 2018; Akinyemi, Ogbuji and Adedokun, 2018; Evans, 2018a). At first, the main monetary policy instrument in Nigeria was the minimum rediscount rate (MRR) (Agu, 2007). In recent years, the monetary policy rate (MPR) has become the main monetary policy instrument. The 
other intervention instruments included open market operations, discount window operations, cash reserve ratio and foreign exchange net open position. However, monetary policy instruments are supposed to be grounded on recognized formulations of their relationships with macroeconomic aggregates. Policymakers are expected to have clear and quantifiable reaction functions identifying a set of variables that forms the monetary policy rule and provides a decent approximation to the interest rates setting practice (Torres, 2002).

Certainly, the controversy in monetary policymaking does not revolve around only the monetary policy rule but more so around what determines how central banks vary the rule over time (Agu, 2007). For instance, the central bank could set the interest rate to adjust to any disequilibrium between output gap, inflation, exchange rate, foreign reserves and openness to trade. Surprisingly, the nature of central banks response in Nigeria and South Africa is not ascertained in the literature. The goal of this study therefore is to model central bank's response to output gap, inflation, exchange rate, foreign reserves and openness to trade in Nigeria and South Africa consistent with recent developments in formulation and estimation of the monetary policy reaction function.

Despite the popularity of inflation targeting, the literature is replete with mixed empirical evidence and substantial controversy in the analysis of the IT framework. There are two main strands in the literature. The first strand addresses the macroeconomic outcomes of IT regimes vis-a-vis non-IT countries. The second strand evaluates central bank behavior under IT and non-IT environment (Clarda, Gali and Gertler., 1998; Aizenman et al, 2008). In this second strand, there are mixed evidences over whether IT adoption changes central banks' behavior, and particularly their responses to output gap and inflation. Within the milieu of the latter strand, this study examines the empirics of central bank operating behavior in Africa. This study therefore focuses particularly on Nigeria and South Africa's central banks' responses to exchange rates, output gaps and inflation, using Taylor rule.

There are many motivations for this study. Firstly, majority of the studies in the literature are focused on IT in developed countries and quite few address the particularities of IT in African countries. There is a need to fill this gap in the literature considering the fact that IT in African countries may differ from industrial countries largely because of challenges associated with limited credibility, weak institutions, and large external shocks (Fraga, Goldjfan and Minella, 2003; Aghion, Bacchetta, Ranciere and Rogoff, 2006; Evans, 2016; Adaramola and Wale-Awe, 2017; Evans, 2018b; Olusoji and Odeleye, 2018). Secondly, whereas in South Africa, a few studies exist on the subject of inflation targeting and central bank reaction to economic variables in their decision making process, there is sparsely any literature on inflation targeting and the reaction function for Nigeria. Thirdly, South Africa is an inflation targeting country while Nigeria is not. There is a need to compare the two countries to determine their central banks' response to key variables such as inflation, output gap, exchange rate, international reserves and openness to trade. The outcome of this level of analysis would assist economists and financial markets in predicting the future path of monetary policy as well as the monetary policy stance of central banks in the two countries.

The rest of the study is laid out as follows. Section 2 examines prior literature on inflation targeting and central bank's reaction function. Section 3 discusses the data 
and the empirical methods. The empirical results are provided and discussed in Section 4, while Section 5 concludes the paper and makes some policy recommendations based on findings.

\section{Literature Review}

2.1. Theoretical Framework. The Taylor rule, proposed by Taylor (1993), and Henderson and McKibbin (1993), is a reduced form approximation of the responses of policy interest rate to changes in output, inflation, or other economic variables. Particularly, the rule describes how the central bank raises the policy interest rate by more than one-percentage point, for every one-percentage point rise in inflation. The goal of the rule is to encourage price stability by decreasing uncertainty and growing the credibility of the central bank's future actions. It avoids the inefficiencies of time non-consistency in the exercise of discretionary monetary policy (Taylor, 2012).

According to Taylor's original rule, interest rate responds to the difference between actual and potential GDP, and also to the difference between actual and targeted inflation rates:

$$
i_{t}=\rho i_{t-1}+\alpha\left(y_{t}-y^{*}\right)+\beta\left(\pi_{t}-\pi^{*}\right)
$$

where $i_{t}$ is the policy interest rate; $i_{t-1}$ is the lagged policy interest rate; $y_{t}-y^{*}$ is the output gap; $\pi_{t}-\pi^{*}$ is the inflation gap.

The rule is therefore based on 3 factors: actual versus targeted inflation levels; actual and potential GDP; and the short-run interest rate consistent with potential GDP. Taylor's rule is therefore a guideline for central banks on how to adjust interest rates in order to change economic conditions. Notwithstanding its limitations and critics, Taylor's rule has become established in central banking for adjusting and setting cautious rates for economic stabilization, while sustaining long-run growth (Branch, 2014; Akinkunmi, 2017; Jung, 2017; Scott and Barari, 2017; Froyen and Guender, 2018).

2.2. Empirical Literature. There is a large body of empirical literature investigating inflation targeting in both advanced industrial economies (Johnson, 2002; Mishkin and Schmidt-Hebbel, 2007; Rose, 2007; Consalves and Salles, 2008; Bordo and Levin, 2017; Bernanke et al., 2018) and developing countries (Mohanty and Klau, 2004; De Mello and Moccero, 2008; Aizenman et al, 2008; Iklaga, 2008; Kelikume and Evans, 2015; Kim and Mehrotra, 2017; Buffie., Airaudo and Zanna, 2018; Valera, Holmes and Hassan, 2018). However, not much has been done with respect to developing countries, compared to the number of studies done for developed countries. There are two main strands in the literature. The first strand addressed the macroeconomic outcomes (e.g., the effects on inflation and inflation volatility) of IT regimes vis-a-vis non-IT countries. These studies employed both individual country time-series and multi-country panels and largely found mixed evidence on IT effects on inflation and other key variables (e.g., Mishkin and SchmidtHebbel, 2007; Anand, Prasad and Zhang, 2015; Baxa, Plaљil and Vаљн ek, 2015; Bernanke, Laubach, Mishkin and Posen, 2018).

For instance, in an important study, Johnson (2002) undertook a panel study of five IT and six non-IT developed countries and found that the announcement of inflation targets depresses expected inflation. Also Mishkin and Schmidt-Hebbel 
(2007) showed that IT helps advanced industrial countries to achieve low inflation in the long run and that there are lower responses of inflation to oil and exchange rate shocks. Rose (2007) argued that IT is a long-run regime in contrast to other monetary rules, and that IT countries have low exchange rate volatility. However, Ball and Sheridan (2005) found no long-run differences between advanced industrial IT and non-IT countries.

For developing countries, Mishkin and Schmidt-Hebbel (2007) found that IT did not perform well compared to similar studies on advanced countries. The IMF (2005) found that IT is connected with a 4.8 percentage-point fall in inflation relative to other monetary regimes. Conzalves and Salles (2008) found that the adoption of IT leads to lower inflation and reduced growth volatility relative to non-IT countries.

The second strand of the literature evaluates central bank behavior under IT and non-IT settings. In this strand, there are mixed empirical evidence over whether IT regime changes central banks' behavior, and particularly their responses to inflation and output gap. These studies also employ both individual country time-series and multi-country panels, investigating differences in IT and non-IT regimes using the Taylor rule and focusing on advanced industrial countries (e.g., Mohanty and Klau, 2005; Schorfheide, 2007); Lubik and Schorfheide (2007) found significant response of interest rates to exchange rate movements in Australia and New Zealand, but not in Canada and the UK. Ravenna (2008), estimating a DSG model for Canada, found that the low average inflation is associated with the credibility of policy under the IT regime. In contrast, Dueker and Fischer (2006) found there is no significant difference in monetary policy rules between IT countries and non-IT countries.

For developing countries, Schmidt-Hebbel and Werner (2002) found that Brazil, Chile and Mexico respond to exchange rate changes in the short-term with inflation targeting. Mohanty and Klau (2004) found that the response of policy to exchange rate is often greater than the response to the output gap and inflation, supporting the "fear of floating" hypothesis. De Mello and Moccero (2008) estimated an interest rate policy function using a New Keynesian structural model for Latin America and found that IT, in a post-1999 regime, is connected with significant responses to expected inflation in Chile and Brazil, while for Mexico, exchange rates fluctuations during the IT period were significant in the central bank's reaction function.

Additionally, Aizenman et al., (2008) examined the role of exchange rate in the IT experiences of emerging market economies, distinguishing between commodity and non-commodity exporting nations. The authors found a significant response from inflation to policy interest rates in IT countries. However, in non-IT regimes, the central banks react less to inflation. The response to real exchange rates was found to be stronger in non-IT regimes, meaning that more constrained policymaking in the IT regime simultaneously target both inflation and exchange rates. For countries embracing IT, the authors found that the strongest response to exchange rates is relatively intensive for countries exporting basic commodities.

For South Africa, Naraidoo and Gupta (2010) found an inflation learning rule for future inflation rates is appropriate for examining the central bank's decision process in its interest rate setting policy. The main findings from Naraidoo and Gupta (2010) are: "(1) that the adoption of inflation targeting led to significant changes in monetary policy; (2) post-2000 monetary policy is asymmetric as policymakers respond more to downward 
deviation of inflation away from the target; (3) post-2000 policymakers may be attempting to keep inflation within the $4.5 \%-6.9 \%$ range rather than pursuing a target zone of 3$6 \%$, as generally pre-announced, and; (4) the response of monetary policy to inflation is nonlinear as interest rates respond more when inflation is further from the target".

For Nigeria, Agu (2007) specified two models, the first grounded on the historical development of the Central Bank while the second grounded on the Taylor rule with the aim of unfolding the Central Bank's reaction function. The author found the primacy of inflation in monetary policy reaction in Nigeria. However, interest rate smoothening behaviour could not be confirmed. Kelikume and Evans (2015), using Granger Causality test and impulse response functions, investigated inflation targeting as a potential monetary framework for Nigeria. The authors showed that inflation respond significantly to exchange rate and interest rate while economic growth responds significantly to exchange rate and inflation. Evans (2018a) showed the non-linear relationship between money, inflation and output with respect to the Friedman and Schwartz hypotheses that monetary policy affects prices in the long-run but not in the short-run, and influences output in the short-run but not in the long-run. Iklaga (2008) found that a Taylor-rule framework is an appropriate tool to summarize the key elements of the central bank's monetary policy stance. The study also, found that inflationary pressures and output play significant roles in the Bank's decisions during the review period.

\section{Data and Methodology}

3.1.Data Description and Sources. This study employs annual data between 1970 and 2016. Interest rate, exchange rate, GDP, inflation, trade openness and foreign reserves data are sourced from World Development Indicators.

3.2. Model Specification. Following a broad literature originating from Taylor (1993), and Henderson and McKibbin (1993), this study adopts a monetary policy reaction function given by:

$$
i_{t}=\rho i_{t-1}+\alpha\left(y_{t}-y^{*}\right)+\beta\left(\pi_{t}-\pi^{*}\right)+\gamma X_{t}
$$

where $X_{t}$ is a set of possible explanatory variables which may be part of the policy reaction function. As is standard in the literature, it is presumed that central banks, in setting interest rates, react to both inflation gap and output gap (Aizenman et al, 2008). Additionally, consistent with English, Nelson and Sack (2003), the policy smoothing goal is assumed to manifest in the lagged interest rate on the right hand side.

In this study, consistent with Aizenman et al (2008) and Odior and Arinze (2017), exchange rate, trade openness and international reserves are included as possible explanatory variables that may also be part of the policy reaction function. It is additionally assumed that the relationship between inflation and interest rate is nonlinear (Naraidoo and Gupta, 2010; Evans, 2018a). Thus, for comparable analysis, the estimated equation for Nigeria and South Africa is:

$$
\begin{aligned}
& \text { Interest }_{t}=\theta_{1} \text { Interest }_{t-1}+\theta_{2} \text { Gdpgap }_{t}+\theta_{3} \text { Inflation }_{t}+\theta_{4} \text { Inflation }_{t}^{2} \\
& +\theta_{5} \text { Exchrate }_{t}+\theta_{6} \text { Trade }_{t}+\theta_{7}{\text { Re } \text { serves }_{t}+\xi_{t}}
\end{aligned}
$$

where Interest is the lending interest rate; Gdpgap is the output gap; Inflation is the consumer price index; Exchange is the exchange rate; Trade is openness to trade; and Reserves is international reserves. 
3.3. Estimation Technique. The estimation techniques used in this study is the fully modi ed least squares (FM-OLS). FM-OLS is a semi-parametric estimation technique; it provides optimal estimates of cointegrating regressions (Evans and Adeola, 2017; Evans, 2019). In contrast to the Johansen and ARDL approach, FMOLS is more robust to endogeneity and serial correlation. Hence the estimates are more robust and more consistent. Additionally, it is applicable irrespective of the order of integration of the variables (whether I(0) or I(1)) (Phillip and Hansen, 1990; Hansen and Kim, 1995). As developed by Phillips and Hansen (1990), Phillips and Moon (1999) and Pedroni (1995; 2000), the FM-OLS estimator uses the initial estimates of the symmetric and one-sided long run covariance matrices of the residuals.

Consider the $\mathrm{n}+1$ dimensional series vector process $(\mathrm{y}, \mathrm{X})$, with the cointegrating equation,

$$
y_{t}=X_{t}^{\prime} \beta+D_{1 t}^{\prime} \gamma_{1}+\mu_{1 t}
$$

Where $X_{t}^{\prime}$ are n stochastic regressors; $D_{t}=D^{\prime}{ }_{1 t}, D^{\prime}{ }_{2 t}$ are the deterministic trend regressors; and $\mu_{1 t}$ are the residuals.

The $\mu_{1 t}$ is obtainable as $\mu_{2 t}=\Delta \varepsilon_{2 t}$ from the levels regressions

$$
X_{t}=\hat{\Gamma}_{1}+\hat{\Gamma}_{2}^{\prime} D_{2 t}+\hat{\varepsilon}_{2 t}
$$

Or from the difference regressions

$$
\Delta X_{t}=\hat{\Gamma}_{1} \Delta D_{1 t}+\hat{\Gamma}_{2}^{\prime} D_{2 t}+\mu_{2 t}
$$

Let $\lambda$ and $\Omega$ be the long run covariance matrices obtainable from the residuals:

$$
\hat{\mu}_{2 t}=\left(\hat{\mu}_{1 t}, \hat{\mu}_{2 t}^{\prime}\right)^{\prime}
$$

Thus the modified data is given as

$$
y_{t}^{+}=y_{t}-\varpi_{12} \Omega_{22}^{-1} \pi_{2}
$$

And the estimated bias correction terms as

$$
\lambda_{t}^{+}=\hat{\lambda}_{12}-\omega_{12} \Omega_{22}^{-1} \hat{\lambda}_{22}
$$

The FMOLS estimator is thus given by

$$
\theta=\left[\begin{array}{l}
\beta \\
\gamma_{1}
\end{array}\right]=\left(\sum_{t=2}^{T} Z_{t} Z_{t}^{\prime}\right)^{-1}\left(\sum_{t=2}^{T} Z_{t} y_{t}^{+}-T\left[\begin{array}{l}
\not_{1} \\
0
\end{array}\right]\right)
$$

Where $Z_{t}=\left(X_{t}^{\prime}, D_{t}^{\prime}\right)$

4. Empirical Results and Discussion. Since most macroeconomic series have unit root (Nelson and Plosser, 1982; Adeola, Boso and Evans, 2018), checking the order of integration of the variables is appropriate. The variables are therefore tested for unit root, using the Elliot, Rothenberg and Stock Point Optimal unit root test (ERS) which is more computationally robust than the traditional unit root tests such as Phillips-Perron (1988) and Augmented Dickey-Fuller (1979) tests. Critical values for the ERS test statistic is computed by interpolating the simulation results from ERS (1996, Table 1, p. 825) for $\mathrm{T}=(50,100,200)$. The results of the ERS unit root test in 
Table 1 indicate stationarity of some variables at $\mathrm{I}(0)$ and some at $\mathrm{I}(1)$, meaning that the variables are a mix of $\mathrm{I}(0)$ and $\mathrm{I}(1)$ which is valid for the FM-OLS approach.

Table 1. Elliott-Rothenberg-Stock Unit Root Test, author's

\begin{tabular}{|c|c|c|c|c|}
\hline & \multicolumn{2}{|c|}{ Nigeria } & \multicolumn{2}{c|}{ South Africa } \\
\hline & $\mathrm{I}(0)$ & $\mathrm{I}(1)$ & $\mathrm{I}(0)$ & $\mathrm{I}(1)$ \\
\hline Interest & 11.11 & $1.06^{*}$ & $3.38^{* * *}$ & $0.51^{*}$ \\
\hline Inflation & $1.64^{*}$ & $0.46^{*}$ & $1.78^{*}$ & $0.51^{*}$ \\
\hline Gdpgap & $2.18^{* *}$ & $3.65^{* * *}$ & $0.62^{*}$ & $0.50^{*}$ \\
\hline Trade & 6.42 & $1.29^{*}$ & 5.22 & $1.06^{*}$ \\
\hline Reserves & 26.72 & $0.88^{*}$ & 37.42 & $1.77^{*}$ \\
\hline Exchrate & 63.17 & $3.12^{* * *}$ & 58.82 & $1.88^{*}$ \\
\hline \multirow{3}{*}{$\begin{array}{c}\text { Test critical } \\
\text { values: }\end{array}$} & $1 \%$ level & 1.870000 & & \\
\cline { 2 - 5 } & $5 \%$ level & 2.970000 & & \\
\cline { 2 - 5 } & $10 \%$ level & 3.910000 & & \\
\hline
\end{tabular}

Note: * significant at $1 \%$; ** significant at $5 \%$; *** significant at $10 \%$. Lag length is selected using Spectral OLS AR based on SIC, maxlag $=9$.

To apply FMOLS for estimation, a cointegrating relationship must first be established among the set of variables (Adeola and Evans, 2017). For that reason, the presence of a cointegrating relation is tested using Hansen Parameter Instability co-integration test. Table 2 shows that the null hypothesis of no co-integration can be rejected for both Nigeria and South Africa. In other words, a long run relationship exists among the variables in the two countries.

Table 2. Hansen Parameter Instability Cointegration Test, author's

\begin{tabular}{|l|l|c|}
\hline & \multicolumn{2}{|c|}{ Cointegrating equation deterministics: C } \\
\hline & Lc statistic & Prob. $^{\text {a }}$ \\
\hline South Africa & $1037.310^{* *}$ & $<0.01$ \\
\hline Nigeria & $5398.758^{* *}$ & $<0.01$ \\
\hline
\end{tabular}

Note: $* *$ significant at $5 \%$. aHansen $(1992 \mathrm{~b}) \mathrm{Lc}(\mathrm{m} 2=4, \mathrm{k}=0) \mathrm{p}$-values, where $\mathrm{m} 2=\mathrm{m}-\mathrm{p} 2$ is the number of stochastic trends in the asymptotic distribution. aHansen (1992b) $\mathrm{Lc}(\mathrm{m} 2=4, \mathrm{k}=0) \mathrm{p}$-values, where $\mathrm{m} 2=\mathrm{m}$-p2 is the number of stochastic trends in the asymptotic distribution.

Having established the presence of long-run relationships among the set of variables, the FMOLS is now implemented. To better assess the robustness of the parameter estimates to different specifications in the two countries, the model is estimated, using 1970-2016 (the full sample) and 1985-2016 as sample periods. The results are the same for both countries. The results in Table 3 show estimates for the Taylor rule regressions employing FM-OLS. The model explains much of the fluctuations in interest rates, the monetary policy variable, in both countries.

Consistent with studies such as Aizenman et al (2008), the degree of persistence of the monetary policy rule, proxied by the coefficient of the lagged interest rate, is rather high. The persistence for South Africa (a IT country) is marginally higher than for Nigeria (a non-IT country). The coefficients of inflation and squared inflation are highly significant for South Africa but not significant for Nigeria. Considering the 
effects and persistence, the long-run response for South Africa is to increase interest rates when inflation increases.

Table 3. Central Banks' Responses to Inflation, Output Gaps, and Exchange Rate in Nigeria and South Africa, author's

\begin{tabular}{|c|c|c|c|c|c|c|}
\hline & \multicolumn{3}{|c|}{ South Africa } & \multicolumn{3}{|c|}{ Nigeria } \\
\hline \multicolumn{7}{|c|}{ Full Sample (1970-2016) } \\
\hline Variable & Coeff. & t-Stat & Prob. & Coeff. & t-Stat & Prob \\
\hline Interest $(-1)$ & $0.95^{*}$ & 12.32 & 0.00 & $0.73 *$ & 8.92 & 0.00 \\
\hline Gdpgap & $13.81^{*}$ & 5.26 & 0.00 & 0.21 & 0.11 & 0.91 \\
\hline Inflation & $1.11^{*}$ & 4.06 & 0.00 & 0.19 & 0.02 & 0.98 \\
\hline Inflation $^{2}$ & $-0.05^{*}$ & -3.63 & 0.00 & -0.07 & -0.61 & 0.55 \\
\hline Exchrate & $0.86^{*}$ & 4.97 & 0.00 & $0.02 * *$ & 2.11 & 0.04 \\
\hline Trade & $0.18^{*}$ & 3.14 & 0.00 & $0.07 * *$ & 2.58 & 0.01 \\
\hline Reserves & $-3.00^{*}$ & -4.53 & 0.00 & $-0.85^{* *}$ & -2.13 & 0.03 \\
\hline$C$ & $50.08^{*}$ & 3.81 & 0.00 & 18.20 & 1.48 & 0.15 \\
\hline \multicolumn{7}{|c|}{$1985-2016$} \\
\hline Variable & Coeff. & t-Stat & Prob. & Coeff. & $\mathrm{t}$-Stat & Prob \\
\hline Interest $(-1)$ & $0.84^{*}$ & 10.32 & 0.00 & $0.46^{*}$ & 4.43 & 0.00 \\
\hline Gdpgap & $11.62^{*}$ & 4.13 & 0.00 & 1.40 & 0.65 & 0.52 \\
\hline Inflation & $1.21^{*}$ & 6.33 & 0.00 & 0.12 & 1.15 & 0.26 \\
\hline Inflation $^{2}$ & $-0.05^{*}$ & -5.78 & 0.00 & -0.10 & -0.67 & 0.51 \\
\hline Exchrate & $0.72^{*}$ & 3.64 & 0.00 & $0.03^{* * *}$ & 2.11 & 0.05 \\
\hline Trade & $0.17^{*}$ & 4.03 & 0.00 & $0.10^{*}$ & 3.59 & 0.00 \\
\hline Reserves & $-3.02^{*}$ & -6.09 & 0.00 & $-1.40^{* * *}$ & -1.89 & 0.07 \\
\hline$C$ & $52.93^{*}$ & 5.55 & 0.00 & $32.94 * * *$ & 2.04 & 0.05 \\
\hline
\end{tabular}

Note: * significant at $1 \% ;{ }^{* *}$ significant at $5 \%$; ** significant at $10 \%$

In Nigeria, policymakers may not respond to inflation in the pronounced way of their South African counterparts: because the coefficients of inflation and squared inflation are not significant for Nigeria. This finding is inconsistent with Agu (2007) and Iklaga (2008) who found that inflationary pressures play significant roles in the Central Bank of Nigeria's decisions.

For South Africa, output gap is significant, while it is not significant for Nigeria. In contrast, Iklaga (2008) found that output play significant roles in the Central Bank of Nigeria's decisions. The coefficients of exchange rates are highly statistically significant for both countries, meaning that both IT and non-IT African central banks respond to exchange rates when setting policy interest rates. However, the response to exchange rate is much higher in South Africa (0.86) than Nigeria (0.02). This is comparable with Kelikume and Evans (2015) who showed that inflation responds to exchange rate and interest rate in Nigeria. Buffie et al (2018) showed that sound management of exchange rate enhances the effectiveness of IT.

Additionally, both countries' central banks ought to consider openness to trade and international reserves in setting their interest rates given their level of significance. While a rise in trade openness leads to higher interest rates, increased reserves lead to lower interest rates. This empirical evidence is consistent with Aizenman et al (2008) who argued that: "If countries are open to trade, they are also more likely to be open to international capital movements. In this case, they may have less control over domestic interest rates and limited ability to respond to real exchange rate 
changes. This effect may dominate their desire to stabilize the economy by more aggressively responding to real exchange rate changes".

The most astonishing and unanticipated finding of this study is that while inflation is positively related to interest rate, squared inflation is negatively related. This suggests that interest rate increases with the increase in inflation but after a certain level of inflation which is the turning point, interest rate starts to decrease. It can be argued that as inflation rises, it becomes more unstable and uncertain. The maturity of debt instruments reduces as the uncertainty rises. Consequently, interest rates are rendered worthless, as the maturity reduces to months or even days. During periods of hyperinflation, the future ceases to exist and cash becomes the only means of exchange as assets with a maturity over a few days is fully wiped out.

5. Conclusion and Policy Implications. This study has examined inflation targeting in Nigeria and South Africa. Using FM-OLS to estimate a modified Taylor rule over the period 1970 to 2016, the study unravels evidence of a significant response from inflation and squared inflation to policy interest rates in South Africa, but not in Nigeria. Overall, South Africa's central bank place much emphasis on inflation targeting in setting interest rates which Nigeria does not. Further, for South Africa, output gap is significant, while it is not significant for Nigeria. The study also reveals that exchange rate, openness to trade and international reserves play significant roles in central bank policy in both countries.

The findings of this study make important points for both central banks in Nigeria and South Africa. First, different monetary policy frameworks have been adopted in both South Africa (e.g., monetary policy strategy included monetaryaggregate targeting, exchange-rate targeting, and discretionary monetary policy) and Nigeria (e.g., direct monetary controls, exchange rate targeting, and monetary targeting). In recent years, South Africa has adopted formal IT while Nigeria's main monetary policy instrument in Nigeria has become the monetary policy rate. However, as illustrated in this study, monetary policy instruments should be grounded on recognized formulations of their relationships with macroeconomic aggregates. Policymakers in the two countries should have clear and quantifiable reaction functions identifying the set of variables that forms the monetary policy rule and therefore provide good approximations to the interest rates setting practice.

At present, inflation (16 percent) and interest rate (25 percent) are very high in Nigeria, and certainly incongruous with the country's macroeconomic stability aspirations. The Central Bank of Nigeria should stabilize fluctuations in money supply, inflation and interest rate in the country. Lending interest rates should be made flexible. Also, appropriate measures should be adopted to raise the value of the naira so as to reduce the inflation rate in the country.

Like South Africa, monetary authorities in Nigeria should make conscious efforts to achieve low and stable inflation rates, also using inflation targeting. In fact, the monetary policy framework of the Central Bank of Nigeria should include implementation of inflation targeting. In line with the literature, for the inflation targeting framework to be most successful in the country, certain prerequisites must be met: "central bank independence, adopting price stability as the sole objective of monetary policy and the existence of a well-developed technical infrastructure. In addition, the impact of fiscal dominance as well as financial, structural and external sector domi- 
nance should be kept at the barest minimum. The independence of a central bank is guaranteed when its monetary policy decisions are not subjected to review by any governmental authority. Such level of independence allows central banks to always have the free will to deploy their policy instruments to target inflation in order to keep it within the agreed band or on the specific target" (Akun et al, 2016). The key merit therefore is better accountability of the central bank in achieving its inflation objectives, built around increased communication with the public, leading to improved market expectations.

However, developing countries' central banks, such as in Nigeria and South Africa, often have weak financial, fiscal and monetary institutions, thus rendering the application of inflation targeting considerably difficult. In this regard, the degree of the triumph of inflation targeting significantly depends on executive capacity, and the political will and commitment on the part of the central banks. The central banks should therefore be flexible about inflation objectives/targets when confronted with more pressing macroeconomic problems that could be remedied using existing policy instruments. From the findings of this study, it can be seen that there is a need to adopt an eclectic approach to setting the monetary policy rule. It is important to set the interest rate to adjust to any observed disequilibrium between output gap, inflation, exchange rate, foreign reserves and openness to trade. In fact, strict inflation targeting may not be an appropriate framework to solve the key macroeconomic problems challenging these African economies, such as price instability, exchange rate stability and inclusive economic growth. Still, inflation targeting remains a relevant policy approach but may not be adequate in its capacity to deal with economic and financial crisis if deployed only.

Adaramola, A., \& Wale-Awe, O. (2017). The relevance of value added reporting in assessing the financial soundness of deposit money banks in Nigeria. BizEcons Quarterly, 1, 3-18.

Adeniji, S. O., Obansa, S. A. J., \& Okoroafor, O. K. (2018). Monetary policy shocks and stock market prices volatility in Nigeria, BizEcons Quarterly, 3, 3-26.

Adeola, O. and Evans, O. (2017). Financial inclusion, financial development, and economic diversification in Nigeria. The Journal of Developing Areas, 51(3), 1-15.

Adeola, O., Boso, N., \& Evans, O. (2018). Drivers of international tourism demand in Africa. Business Economics, 53(1), 25-36.

Aghion, P., P. Bacchetta, R. Ranciere and K. Rogoff (2006). Exchange Rate Volatility and Productivity Growth: The Role of Financial Development. NBER Working Paper No. 12117 (March).

Agu, C. (2007). What Does the Central Bank of Nigeria Target? An Analysis of the Monetary Policy Reaction Function in Nigeria. In Report presented at the Biannual research workshop of the African Economic Research Consortium, Arusha, Tanzania.

Aizenman, J. Hutchison, M. and Noy, I. (2008). Inflation targeting and real exchange rates in emerging markets, Working Papers, UC Santa Cruz, Economics Department, No. 648

Akinkunmi, M. A. (2017). Monetary policy decisions in selected Organization of Petroleum Exporting Countries economies: does Taylor's principle matter?. OPEC Energy Review, 41(2), 115-131.

Akinyemi, A. K., Ogbuji, A. I., \& Adedokun, A. S., (2018). Manufacturing Sector Performance in Africa: The Role of Monetary Policy Instruments, Business and Economic Quarterly, 2, 36-47.

Akuns, J. S, Obioma, E. C., Udoh, E. A. P, Uzonwanne, G. C., Adeleke, A. I., and Mohammed, A. A., (2016) Relevance of Inflation Targeting for Developing Countries in the New Normal: A Case of Nigeria, CBN/WPS/01/2016/01

Anand, R., Prasad, E. S., \& Zhang, B. (2015). What measure of inflation should a developing country central bank target?. Journal of Monetary Economics, 74, 102-116.

Ball, L. and N. Sheridan (2005). Does inflation targeting matter? In Monetary Policy under Inflation Targeting, edited by F. Mishkin and K. Schmidt-Hebbel. Santiago: Central Bank of Chile. 
Bassey, G. E. and Essien, E. B. (2014). Inflation Targeting Framework for Monetary Policy in Nigeria: Issues, Problems and Prospects. Journal of Economics and Sustainable Development, 5(12), 88101.

Ваха, J., Plaљil, M., \& Уаљн ek, В. (2015). Changes in inflation dynamics under inflation targeting? Evidence from Central European countries. Economic Modelling, 44, 116-130.

Bernanke, B. S., Laubach, T., Mishkin, F. S. and Posen, A. S. (2018). Inflation targeting: lessons from the international experience. Princeton University Press.

Bernanke, B. S., Laubach, T., Mishkin, F. S., \& Posen, A. S. (2018). Inflation targeting: lessons from the international experience. Princeton University Press.

Bordo, M. D. and Levin, A. T. (2017). Central bank digital currency and the future of monetary policy (No. w23711). National Bureau of Economic Research.

Branch, W. A. (2014). Nowcasting and the Taylor rule. Journal of Money, Credit and Banking, 46(5), 1035-1055.

Buffie, E. F., Airaudo, M., \& Zanna, F. (2018). Inflation targeting and exchange rate management in less developed countries. Journal of International Money and Finance, 81, 159-184.

Clardia, R. H., J. Gali, and M. Gertler (1998). "Monetary Policy Rules in Practice: Some International Evidence,” European Economic Review (June).

Conзalves, Carlos Eduardo S., and Јого M. Salles (2008). "Inflation targeting in emerging economies: What do the data say?” Journal of Development Economics 85, 312-318.

Corbo, V., O. Landerretche and K. Schmidt-Hebbel (2001). "Assessing Inflation Targeting After a Decade of World Experience," International Journal of Finance and Economics 6 (343-368).

De Mello, L. (2008). Monetary Policies and Inflation Targeting in Emerging Economies (edited volume). OECD (Paris).

Dickey, D. A. and Fuller, W. A. (1979). Distribution of the estimators for autoregressive time series with a unit root. Journal of the American statistical association, 74(366a), 427-431.

Dueker, M. and A. Fischer (2006). "Do Inflation Targeters Outperform Nontargeters?" Federal Reserve Bank of St. Louis Review September/October, pp. 431-450.

Elliott, G., Rothenberg, T.J. and Stock, J.H. (1996), Efficient Tests for an Autoregressive Unit Root, Econometrica, Vol. 64, No. 4, 813-836.

English, W. B., Nelson, W. R. and Sack, B. P. (2003). Interpreting the significance of the lagged interest rate in estimated monetary policy rules. Contributions in Macroeconomics, 3(1).

Evans, O. (2016). The effectiveness of monetary policy in Africa: modeling the impact of financial inclusion. Iranian Economic Review, 20(3), 327-337.

Evans, O. (2017) Threshold Effects in the Relationship between Interest Rate and Financial Inclusion in Nigeria. Journal of Economics and Business Research, 23(1), 7-22.

Evans, O. (2018a). Money, Inflation and Output in Nigeria and South Africa: Could Friedman and Schwartz Be Right? Journal of African Business.

Evans, O. (2018b). Improved Financial Performance Without Improved Operational Efficiency: The Case of Nigerian Firms. Forum Scientiae Oeconomia, 6(3), 25-39.

Evans, O. (2019). Blockchain Technology and the Financial Market: An Empirical Analysis. Actual Problems of Economics.

Evans, O., \& Saibu, O. (2017) Quantifying the impact of monetary and exchange rate policies on economic diversification in Nigeria. Nigerian Journal of Economic and Social Studies, 59(1), 131-152.

Evans, O., Adeniji, S. O., Nwaogwugwu, I., Kelikume, I., Dakare, O., \& Oke O. O. (2018). The relative effect of monetary and fiscal policy on economic development in Africa: a GMM approach to the St. Louis equation. BizEcons Quarterly, 2, 3-23.

Fraga, A., Goldjfan, I. and Minella, A. (2003). Inflation Targeting in Emerging Market Economies. NBER Macroeconomics Annual.

Froyen, R. T., \& Guender, A. V. (2018). The real exchange rate in Taylor rules: A Re-Assessment. Economic Modelling.

Henderson, D. W., \& McKibbin, W. J. (1993). A comparison of some basic monetary policy regimes for open economies: implications of different degrees of instrument adjustment and wage persistence. In Carnegie-Rochester Conference Series on Public Policy (Vol. 39, pp. 221-317). North-Holland.

Iklaga, F. O. (2008). Estimating Monetary Policy Reaction Functions for the Central Bank of Nigeria, 1999-2007. Unpublished Paper.

International Monetary Fund (2005). World Economic Outlook. Washington, D.C.

Johnson, D. (2002). The effect of inflation targeting on the behavior of expected inflation: evidence from an 11 country panel, Journal of Monetary Economics 49, 15211538. 
Jonsson G (2001). Inflation, Money Demand, and Purchasing Power Parity in South Africa. IMF Staff Papers, 48 (2).

Jung, A. (2017). Does McCallum's rule outperform Taylor's rule during the financial crisis?. The Quarterly Review of Economics and Finance.

Katusiime, L. and Agbola, F. W. (2018). Modelling the impact of central bank intervention on exchange rate volatility under inflation targeting. Applied Economics, 1-14.

Kelikume, I. and Evans, O. (2015). Inflation targeting as a possible monetary framework for Nigeria. The International Journal of Business and Finance Research, 9(5), 71-81.

Kim, S., \& Mehrotra, A. (2017). Managing price and financial stability objectives in inflation targeting economies in Asia and the Pacific. Journal of Financial Stability, 29, 106-116.

Lubik, T. A. and Schorfheide, F. (2007). Do central banks respond to exchange rate movements? A structural investigation. Journal of Monetary Economics, 54(4), 1069-1087.

Mishkin, F. S. and Schmidt-Hebbel, K. (2007). Does inflation targeting make a difference? NBER Working Paper 12876.

Mohanty, M.S. and M. Klau (2004). Monetary policy reules in emerging market economies: issues and evidence, BIS Working Paper No. 149 (March).

Naraidoo, R. and Gupta, R. (2010). Modeling monetary policy in South Africa: Focus on inflation targeting era using a simple learning rule. International Business \& Economics Research Journal (IBER), 9(12).

Nelson, C. R. and Plosser, C. R. (1982). Trends and random walks in macroeconmic time series: some evidence and implications. Journal of monetary economics, 10(2), 139-162.

Nwaogwugwu, I., \& Evans, O. (2016). A sectoral analysis of fiscal and monetary actions in Nigeria. The Journal of Developing Areas, 50(4), 211-230.

Odior, E., \& Arinze, S. (2017). The Dynamics of Inflation, Public Debt and Exchange Rate in Nigeria. BizEcons Quarterly, 1, 19-34.

Olusoji, M. O., \& Odeleye, A. T. (2018). Service sector potentials in the transformation of the Nigerian economy. BizEcons Quarterly, 2, 24-35.

Pedroni P (1995), Panel Co-integration: Asymptotic and Unite Sample Properties of PooledTime Series Test with an Application to the PPP Hypothesis, Indiana University Working Papers in Economics No. 95-013.

Pedroni P (2000), Fully Modified OLS for Heterogeneous Co-integrated Panels, in BaltagiB (Ed.), Non-Stationary Panels, Panel Co-Integration, and Dynamic Panels, Advances in Econometrics, Vol. 15, pp. 93-130, JAI Press, Amsterdam.

Phillips P C B and Moon H R (1999), Linear Regression Limit Theory for Non-Stationary Panel

Data, Econometrica, Vol. 67, pp. 1057-1111.

Phillips P. C. B. and Hansen B. E. (1990), Statistical Inference in Instrumental Variable Regression with I (1) Processes, Rev. Econ. Studies, Vol. 57, pp. 99-125.

Phillips, P. C. and Perron, P. (1988). Testing for a unit root in time series regression. Biometrika, 75(2), 335-346.

Ravenna, F. (2008). The Impact of Inflation Targeting: Testing the Good Luck Hypothesis. Mimeo. University of California, Santa Cruz, Department of Economics.

Rose, A. (2007). A stable international monetary system emerges: Inflation targeting is Bretton Woods, reversed. Journal of International Money and Finance 26, 663-681.

Saibu, M. O., Alenoghena R. O., Evans, O., \& Tewogbade, S. (2016). Determinants of Stock Trading Volume in Nigeria: Money Demand Approach. Journal of Empirical Economics, 5(2), 74-89.

Schmidt-Hebbel, K. and Alejandro Werner (2002). Inflation Targeting in Brazil, Chile and Mexico: Performance, Credibility, and the Exchange Rate, Economia (Spring), 31-89.

Scott, C. P., \& Barari, M. (2017). Monetary policy deviations: A Bayesian state-space analysis. The Quarterly Review of Economics and Finance, 63, 1-12.

Taylor, J. B. (1993). Discretion versus policy rules in practice. In Carnegie-Rochester conference series on public policy (Vol. 39, pp. 195-214). North-Holland.

Taylor, J. B. (2012). First Principles: Five Keys to Restoring America's Prosperity. WW Norton \& Company.

Torres, A. (2002) Monetary policy and interest rates: evidence from Mexico Banco de Mйxico, Banco de Mйxico, Av. 5 de Mayo \#18 5to piso, Mexico City, C.P. 06059

Valera, H. G. A., Holmes, M. J., \& Hassan, G. M. (2018). Is inflation targeting credible in Asia? A panel GARCH approach. Empirical Economics, 54(2), 523-546.

van der Merwe E. J. (2004). Inflation targeting in South Africa. South African Reserve Bank Occasional Paper, No. 19. 